Received 12.01.2016 Reviewed 19.02 .2016 Accepted 29.02.2016

A - study design

B - data collection

C - statistical analysis

D - data interpretation

E - manuscript preparation

F - literature search

\section{Analysis of hydraulic load of a wastewater treatment plant in Jasło}

\author{
Dariusz MEYŃSKI ${ }^{1)} \mathrm{ABCDEF}$, Krzysztof CHMIELOWSKI ${ }^{1)} \mathrm{ABCDEF}$, \\ Anna MŁYŃSKA ${ }^{2) ~ A B C D E F ~}$
}

\footnotetext{
${ }^{1)}$ University of Agriculture in Cracow, Department of Sanitary Engineering and Water Management, al. Mickiewicza 24/28, 30-059 Kraków, Poland; e-mail: dariusz.mlynski@gmail.com

${ }^{2)}$ Cracow University of Technology, Institute of Water Supply and Environment Protection, ul. Warszawska 24, 31-155 Kraków, Poland
}

For citation: Młyński D., Chmielowski K., Młyńska A. 2016. Analysis of hydraulic load of a wastewater treatment plant in Jasło. Journal of Water and Land Development. No. 28 p. 61-67.

\begin{abstract}
The paper presents an analysis of hydraulic load in a wastewater treatment plant (WTP) in Jasło. The study was based on the records of daily sewage volume entering the treatment plant within a multi-year period of 2010-2014. The analysis took into account the average daily amount of incoming sewage, the maximum daily peaking factor for the incoming sewage, changes in the sewage volume depending on specific month and day of a week, and class intervals with the greatest frequency of occurrence.

The analysis revealed that the average daily volume of the sewage entering the WTP in Jasło in the investigated multi-year period was $13045 \mathrm{~m}^{3} \cdot \mathrm{d}^{-1}$. The amount of incoming sewage was variable, as evidenced by the maximum peaking factors of daily sewage inflow that ranged from 1.07 to 2.78 , depending on a specific month. The sewage admission was the largest in March, May and June and on Saturdays. Sewage volume interval most often occurring at the WTP in Jasło was the one between 8000 and $10000 \mathrm{~m}^{3} \cdot \mathrm{d}^{-1}$. The study results indicated that the facility was hydraulically underloaded.
\end{abstract}

Key words: hydraulic load, sewage, sewage amount, wastewater treatment plant

\section{INTRODUCTION}

One of the main and widely investigated fields of water and wastewater management is the problem of discharging and treating the sewage generated in the course of human economic activities [BERGEL et al. 2013]. The problem is important, as the sewage pose a threat to both humans and the environment. This requires a construction of efficient sewerage systems discharging wastewater into treatment plants [MIKOŁAJCZYK, KRAJEWSKI 2014]. To correctly assess the dimensions of a sewerage system, it is necessary to determine water needs of a human population [BERGEL, PAWELEK 2005]. An important parameter in this aspect is unit water consumption that directly trans- lates into the amount of generated sewage. Unit water consumption depends on water and sewage system installed in a dwelling, sanitary habits of residents, their age and sewage discharge system [PAWEŁEK, KACZOR 2006]. When the nature of water consumption by residents is known for a reasonable period of time, a hydraulic load of a treatment plant may be determined with a certain probability [KACZOR 2009].

In the recent years, the amount of domestic sewage has been on the rise. This is due to a continuous development of water supply systems and construction of buildings equipped with a complete water and sewage system. As a result, water consumption and consequently the amount of discharged sewage increase [BUGAJSKI, BERGEL 2009; BUGAJSKI, KACZOR 
2005; BugAJSKI, PAWEŁEK 2005]. Increased amount of sewage inflowing a wastewater treatment plant (WTP) may be also due to other factors, such as mechanical damage or leaks in the sewerage pipes that transport also infiltration waters [KACZOR, PRZEBINDA 2009]. In extreme cases, the water inflowing a sewerage system from outside the pipes may cause even fivefold increase in average daily sewage admission [KACZOR, PAWEŁEK 1999]. This may cause a hydraulic overload affecting the efficiency of technological devices or leaching of active sludge from a bioreactor [KACZOR 2011; TOET et al. 2005; XU et al. 2015]. However, hydraulic underload is another problem faced by the treatment plant operators. It may disturb consecutive steps of sewage treatment, as the processes of pollution removal require certain amount of sewage to be effective [BUGAJSKI 2007; GIOKAS et al. 2002; SPELLMAN 2013].

Since Poland's accession to the European Union, a significant improvement in water and sewage management has been noticed in both urban and rural areas. Poland, as a member of the European Union, is committed to implementation of the Water Framework Directive (WFD), which requires all member states to rationally use and protect water resources. Implementation of WFD's provisions resulted in the introduction of the National Sewage Treatment Programme. It states that agglomerations with population equivalent (PE) of at least 2000 must have collective sewerage systems discharging the sewage into wastewater treatment plants [CHMIELOWSKI et al. 2015; MIERNIK, MŁYŃSKI 2014].

The facility in Jasło is one of such WTPs. Its responsibility is to dispose of physical and oxygendemanding contaminants and nutrients admitted with the sewage discharged from Jasło agglomeration with 72613 PE [MASŁON 2014]. Bearing in mind the results of hydraulic overload and underload and the implementation of WFD, the aim of this paper was to analyze the amount of sewage inflowing the treatment plant in Jasło, based on the total amount of sewage disposed of at this facility.

\section{DESCRIPTION OF THE STUDY OBJECT}

The wastewater treatment plant in Jasło is a facility combining mechanical and biological methods of sewage treatment and using an active sludge in the biological phase. Designed capacity of the treatment plant in the dry season is $20000 \mathrm{~m}^{3} \cdot \mathrm{d}^{-1}$, and in the wet season $72000 \mathrm{~m}^{3} \cdot \mathrm{d}^{-1}$. A simplified diagram of the Jasło treatment plant is presented in Figure 1.

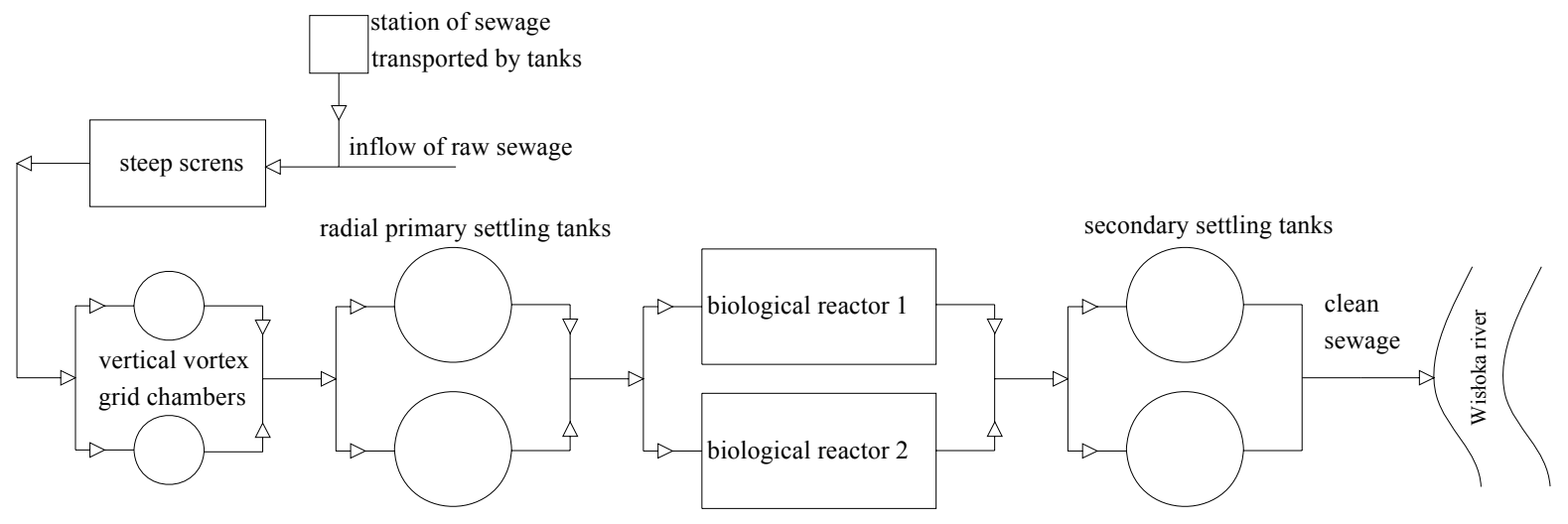

Fig. 1. A simplified diagram of the wastewater treatment plant in Jasło; source: own elaboration

Mechanical treatment involves step screens, two vertical vortex grit chambers and two radial primary settling tanks. Biological treatment is performed in two bioreactors utilizing the Bardenpho process. Before the treated sewage is discharged into the receiving water, it is directed to two secondary settling tanks to separate the active sludge from the treated sewage. At the end of the process, the treated sewage is discharged into the receiving water, i.e. the Wisłoka River.

\section{MATERIALS AND METHODS}

The analysis of hydraulic loading of the Jasło wastewater treatment plant was based on the data of daily records of sewage volume admitted into the facility in the years 2010-2014. The data were provided by Jasło Public Utility Department. They were used to determine descriptive statistics such as the measures of location: maximum $\left(Q_{d \max }\right)$, medium $\left(Q_{d \mathrm{avg}}\right)$, modal $\left(M_{o}\right)$, and minimum $\left(Q_{d \min }\right)$ daily volume of sewage admitted to the facility within the investigated multiyear period, and the measures of spread: standard deviation $(s)$ and coefficient of variation $\left(V_{s}\right)$.

Maximum daily peaking factors of sewage admission $\left(N_{d \max }\right)$ were determined according to the following formula [HEIDRICH 1998]:

$$
N_{d \max }=\frac{Q_{d \max }}{Q_{d \text { avg }}}
$$

where:

$Q_{d \max }=$ maximum daily sewage volume inflowing the treatment plant $\left(\mathrm{m}^{3} \cdot \mathrm{d}^{-1}\right)$, within the study period; 
$Q_{\text {davg }}=$ average daily sewage volume inflowing the treatment plant $\left(\mathrm{m}^{3} \cdot \mathrm{d}^{-1}\right)$, within the study period.

$Q_{d \text { avg }}$ was determined for individual months and days of the week. The significance of differences in $Q_{d a v g}$ for individual months and days of the week for the significance level $\alpha=0.05$ was assessed using Kruskal-Wallis and $\chi^{2}$ tests [SPELLMAN 2005].

Furthermore, histograms and empirical cumulative distribution function of the sewage volume inflowing the WTP in Jasło were determined for the years 2010-2014. The number of intervals and their width were worked out using the formulas employed by MIERNIK and WAtĘGA [2013]:

$$
L_{k} \approx 5 \log N
$$

where:

$L_{k}=$ number of right-open class intervals,

$N=$ number of data in the observation sequence.

$$
\Delta=\frac{Q_{d \max }-Q_{d \min }}{L_{k}}
$$

where:

$\Delta \quad=$ width of the class interval, $\mathrm{m}^{3} \cdot \mathrm{d}^{-1}$;

$Q_{d \max }=$ maximum daily sewage volume inflowing the treatment plant $\left(\mathrm{m}^{3} \cdot \mathrm{d}^{-1}\right)$, within the study period;

$Q_{d \min }=$ minimum daily sewage volume inflowing the treatment plant $\left(\mathrm{m}^{3} \cdot \mathrm{d}^{-1}\right)$, within the study period.

\section{STUDY RESULTS}

The data collected in the course of the study were used to prepare a graph presenting daily volume of sewage inflowing the wastewater treatment plant in Jasło in the years 2010-2014 (Fig. 2). The values of individual statistical parameters and maximum daily peaking factors for sewage admission (Tab. 1) describe the dynamics of changes in the daily amount of sewage inflowing the facility.

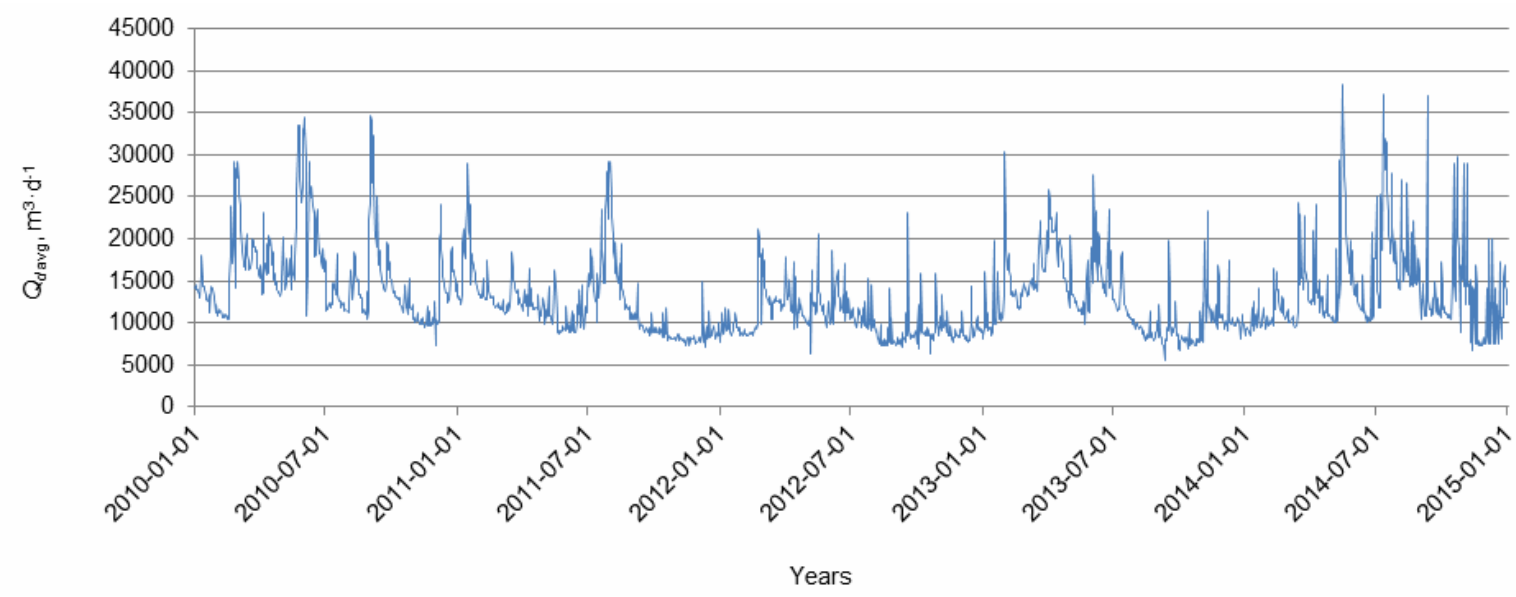

Fig. 2. The amount of sewage inflowing the wastewater treatment plant in Jasło in the years 2010-2014; source: own elaboration

Table 1. Parameters describing sewage admission into the Jasło wastewater treatment plant in individual years and the entire study period

\begin{tabular}{|c|c|r|r|r|r|r|r|}
\hline \multirow{2}{*}{ Study parameter } & \multirow{2}{*}{ Unit } & \multicolumn{7}{|c|}{ Parameter value } \\
\cline { 3 - 8 } & & 2010 & 2011 & 2012 & 2013 & 2014 & $2010-2014$ \\
\hline$Q_{d \max }$ & $\mathrm{m}^{3} \cdot \mathrm{d}^{-1}$ & 34694 & 29296 & 23140 & 30472 & 38434 & 38434 \\
\hline$Q_{\text {davg }}$ & $\mathrm{m}^{3} \cdot \mathrm{d}^{-1}$ & 14018 & 12113 & 10436 & 12622 & 14125 & 13045 \\
\hline$Q_{d \min }$ & $\mathrm{m}^{3} \cdot \mathrm{d}^{-1}$ & 7209 & 7084 & 6345 & 5455 & 6722 & 5455 \\
\hline$s$ & $\mathrm{~m}^{3} \cdot \mathrm{d}^{-1}$ & 5338 & 4133 & 2594 & 4253 & 5531 & 4860 \\
\hline$V_{s}$ & - & 0.38 & 0.34 & 0.25 & 0.34 & 0.39 & 0.37 \\
\hline$M_{o}$ & $\mathrm{~m}^{3} \cdot \mathrm{d}^{-1}$ & 13969 & 8198 & 8601 & 9478 & 8031 & 8031 \\
\hline$N_{d \max }$ & - & 2.48 & 2.42 & 2.22 & 2.41 & 2.72 & 2.95 \\
\hline
\end{tabular}

Source: own elaboration.

The data presented in Figure 2 and the results compiled in Table 1 revealed that $Q_{d \min }$ of the sewage inflowing the WTP in the years 2010-2014 was observed in 2013 and was nearly $5500 \mathrm{~m}^{3} \cdot \mathrm{d}^{-1} \cdot Q_{d \max }$ amounting to nearly $38500 \mathrm{~m}^{3} \cdot \mathrm{d}^{-1}$ was recorded in 2014. Therefore, $Q_{\text {davg }}$ of the sewage inflowing the Jasło WTP in the years $2010-2014$ was $13045 \mathrm{~m}^{3} \cdot \mathrm{d}^{-1}$.
According to MUCHA'S classification [1994], the coefficient of variation for the sewage volume inflowing the treatment plant each day, which for the investigated period was below $40 \%$, indicated moderate variation in the volume of admitted sewage. $N_{d \max }$ for the years 2010-2014 was 2.95. Moreover, based on results which are presented in table, it was conclude, 
that volume of inflowing sewage to sewage treatment plant in Jasło is greater in relative to currently accepted unit consumption of water per day per person (actually to design is it $0.12 \mathrm{~m}^{3} \cdot \mathrm{d}^{-1} \cdot \mathrm{P}^{-1}$ ) and population equivalent. The length of the sanitary sewage system of Jasło is equal to $350.8 \mathrm{~km}$. The length of the combined sewage system is equal to $34.9 \mathrm{~km}$ (it is over 9-percentage part of the total length of the sewage system). Total length of the sewage system is equal to $385.7 \mathrm{~km}$. The length of the rain water sewage system is equal to $16.1 \mathrm{~km}$ (probably it is independent sewage system and it doesn't discharge rain water to the treatment plant). Considering information, it can be supposed that increased sewage inflow to wastewater treatment plant related to PE can be caused by infiltration water and accidental water. To identify the reason of increased sewage inflow, it is necessary to perform additional study deal with sewage inflow during night and determine the percentage value of infiltration water and accidental water related to the total amount of sewage.

$Q_{d \max }$ and $Q_{d \text { avg }}$ are some of the most important parameters to be considered during design, construction and operation of wastewater treatment plants [KŁACZYŃSKI, RATAJCZAK 2012]. Therefore, the equation (1) was used to determine $N_{d \max }$ of the sewage inflowing the Jasło treatment plant in individual months of 2010-2014 period. The resulting $N_{d \max }$ values are presented in Figure 3.

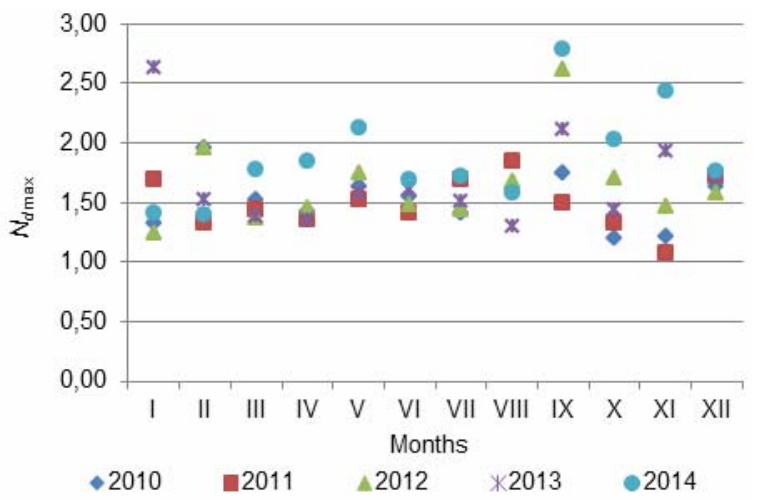

Fig. 3. $N_{d \max }$ for individual months within the years 2010-2014; source: own elaboration

In the investigated multi-annual period, $N_{d \max }$ for individual months ranged from 1.07 to 2.78 . The lowest $N_{d \max }$ was calculated for November 2011 and the highest for September 2014. The main reason for $N_{d \max }$ variation is the effect exerted on the sewerage system by of extraneous water [MINES et al. 2007; MŁYŃSKA 2014]. An analysis of $N_{d \max }$ for the individual months as well as for the entire investigated period (Tab. 1) revealed that the values of this parameter were different from those reported in the literature. This is very important for predicting the amount of wastewater discharged from a specific area. As claimed by MYSZOGRAJ and PANEK [2007], the amount of sewage discharged from a defined settlement unit with over $25 \mathrm{k}$ inhabitants is forecast assum- ing $N_{d \max }$ of 1.2. When this reference value was used for the Jasło population comprising over $33 \mathrm{k}$ of inhabitants, the calculated $N_{d \max }$ for the individual months, years and the entire investigated period 2010-2014 was different than that predicted by MYSZOGRAJ and PANEK [2007]. Assuming too low $N_{d \text { max }}$ at the design stage may cause periodic hydraulic overload of a wastewater treatment plant that may disturb the processes of removing contaminants from the treated sewage.

Figure 4 shows $Q_{d \text { avg }}$ changes in specific months against the design capacity of the Jasło WTP and $Q_{d \text { avg }}$ determined for the years 2010-2014. The aim of the analysis was to identify the months with the lowest and the highest $Q_{d \text { avg }}$ within the five-year period.

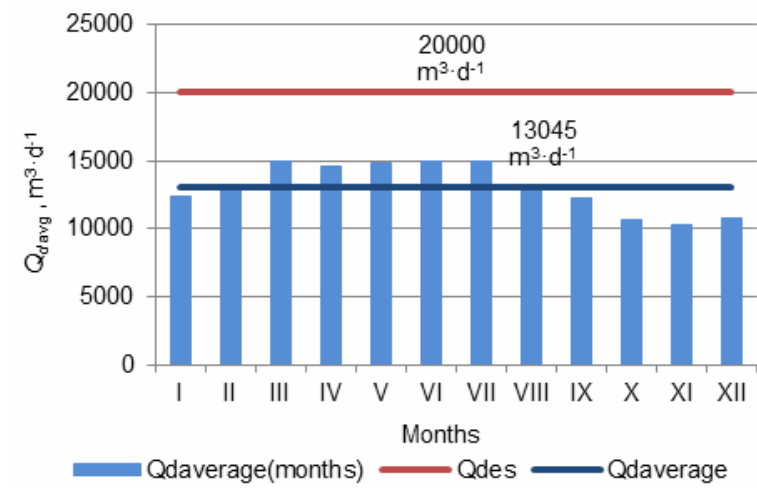

Fig. 4. Average daily amount of sewage inflowing the wastewater treatment plant in Jasło in individual months of the years 2010-2014; source: own elaboration

The results presented in Figure 4 indicate that $Q_{d \text { avg }}$ of the sewage inflowing the Jasło facility differ significantly between individual months. This is confirmed by $\chi^{2}=367.97$ that assumed values above $\chi_{k r}^{2}$ $\left(\chi_{k r}^{2}=21.026\right.$ for $\alpha=0.05$ and $\left.k=12\right)$. The highest $Q_{d \text { avg }}$ for the sewage inflowing the Jasło WTP was recorded in March, June and July - almost 15000 $\mathrm{m}^{3} \cdot \mathrm{d}^{-1}$. The lowest $Q_{d \text { avg }}$ was recorded in November and amounted to nearly $10300 \mathrm{~m}^{3} \cdot \mathrm{d}^{-1}$. Moreover, it was observed that $Q_{\text {davg }}$ was higher in the first half of each investigated year in the period of 2010-2014. However, the design capacity of the wastewater treatment plant was never exceeded. It seems highly probable that $Q_{d \text { avg }}$ distribution for the sewage inflowing the Jasło facility is mainly affected by the extraneous water. In early spring (March) it was probably mostly meltwater from melting snow cover. In late spring and summer (May, June and July) it was rainwater. This water infiltrated through leaks in the sewerage system or holes in the manholes or was illegally discharged from roof gutter outlets and yard gullies connected to the sanitary sewerage system [KACZOR 2011; KACZOR et al. 2013; RAUCH, HARREMOES 1996; STRICKER et al. 2003].

The analysis of hydraulic load of the Jasło facility was supplemented with determination of $Q_{d \text { avg }}$ for specific weekdays of the investigated period. The analysis outcomes are presented in Figure 5. 


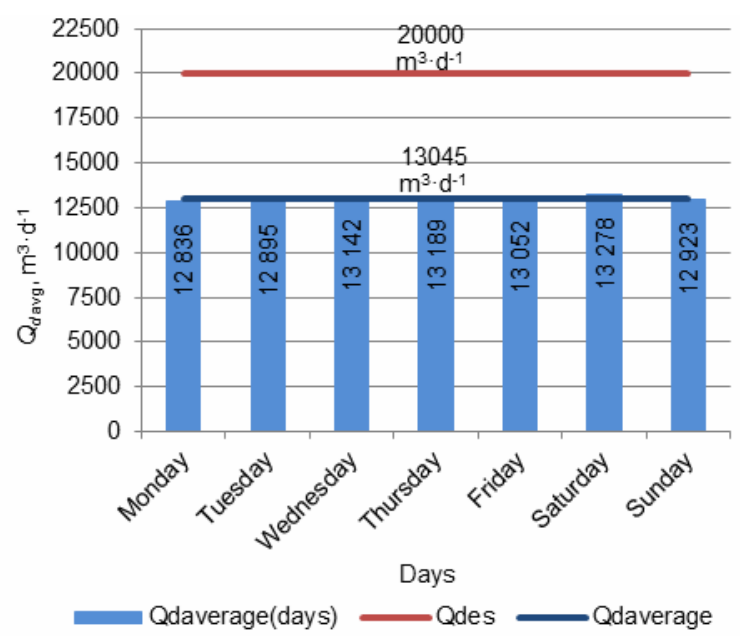

Fig. 5. Average daily amount of sewage inflowing the wastewater treatment plant in Jasło on individual weekdays of the years 2010-2014; source: own elaboration

The values statement on Figure 5 has been calculated, based on daily inflow of sewage to wastewater treatment plant in Jasło, in each days of weeks, throughout the analyzed multi-year. A scrutiny of the data presented in Figure 5 revealed that the amount of sewage inflowing the Jasło WTP is similar on all days of the week. This was confirmed by the value of $\chi^{2}$ for the amounts of sewage admitted on specific weekdays. It was equal to 1.55 and thus lower than $\chi_{k r}^{2}$ that for $k=7$ and $\alpha=0.05$ was 14.067 . Therefore, the differences between the amount of sewage entering the facility on specific weekdays were not significant. The highest sewage admission in the investigated period was reported for Saturdays (nearly $13300 \mathrm{~m}^{3} \cdot \mathrm{d}^{-1}$ ) and the lowest for Mondays (nearly $12840 \mathrm{~m}^{3} \cdot \mathrm{d}^{-1}$ ). Similar results were published by KACZOR [2006]. He indicated that the amount of discharged sewage corresponded to the general weekly pattern of water consumption. This means that the greatest amount of sewage is discharged on Saturdays and the lowest on Sundays and holidays.

The final stage of the analysis of hydraulic load dynamics in the Jasło wastewater treatment plant involved determining the frequency of different sewage inflows and their probability of occurrence. The number of class intervals and their width were determined based on equations (2) and (3). For the investigated multi-year period, there were 19 class intervals per $2000 \mathrm{~m}^{3} \cdot \mathrm{d}^{-1}$ each. The frequency of individual inflows together with empirical cumulative distribution function are presented in Figure 6.

The data compiled in Figure 6 indicated that $Q_{d \text { avg }}$ of the sewage entering the WTP in Jasło most often ranged between 8000 and $10000 \mathrm{~m}^{3} \cdot \mathrm{d}^{-1}$. This class amounted to $24 \%$ of all recorded sewage admission. The empirical cumulative distribution functions revealed that the probability of sewage inflow exceeding the design capacity of the facility for the dry season was about $8 \%$.

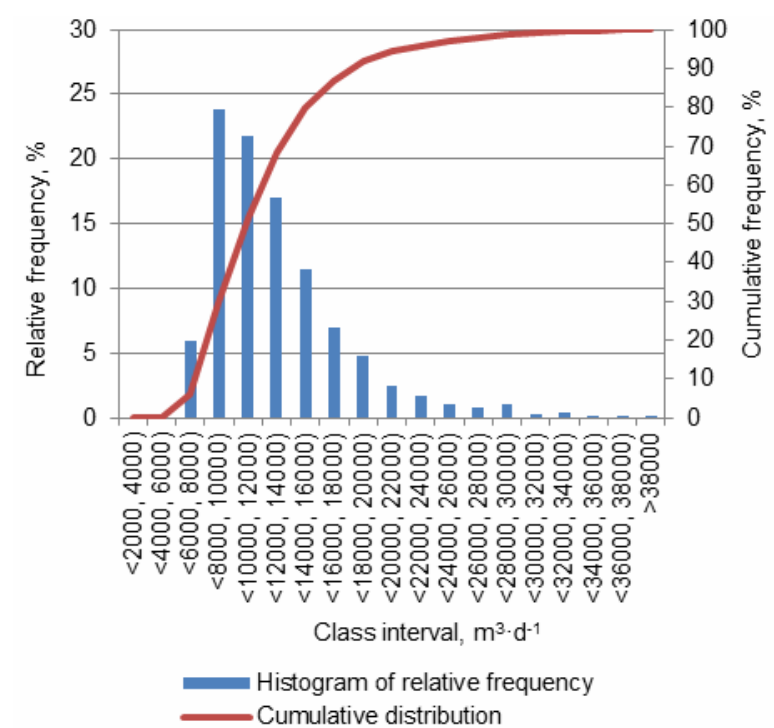

Fig. 6. Histogram of relative frequency and empirical cumulative distribution function for the amount of sewage inflowing the wastewater treatment plant in Jasło in the years 2010-2014; source: own elaboration

\section{CONCLUSIONS}

1. Average daily amount of sewage inflowing the Jasło WTP in the years 2010-2014 was $13045 \mathrm{~m}^{3} \cdot \mathrm{d}^{-1}$. This amounts to $67 \%$ of the facility design capacity. There were a few situations in which the sewage amount admitted to the treatment plant exceeded the average amount for the investigated period by a few times (particularly in 2010). This is explained mainly by intense precipitation that occurred in the Subcarpathian region in 2010 [LIPIŃSKA (ed.) 2011].

2. The amount of sewage inflowing the Jasło WTP in the years 2010-2014 was highly variable. This was evidenced by $N_{d \max }$ values that for both individual years and the entire investigated period significantly exceeded 2.00. Whereas the most often occurring amount of sewage was the one in the range 8000 to $10000 \mathrm{~m}^{3} \cdot \mathrm{d}^{-1}$. This class interval accounted for $24 \%$ of all recorded inflows.

3. The greatest daily amount of sewage entered the Jasło facility in the early and late spring (March and May) and early summer (June and July), what corresponded with the effects of extraneous water (meltwater and rainwater) on the sewerage system. It is suggest to perform studies deal with the volume of sewage inflowing to wastewater treatment plant during night. It would give the treatment plant operator information about the size of percentage value of the infiltration water and accidental water related to the total amount of sewage. It is suggest to perform detailed study on the particular sewage system section to prove where the largest quantities of infiltration water and accidental water inflow to sewage system. If sew age system is leaky, it could be propose to perform sewage system renovation with using e.g. resin- 
saturated felt tube made of polyester and nylon fibers. The analysis of the age structure and material structure of sewage system in Jasło should be perform. It would indicate which sewage system section is the most endangered with the infiltration water and accidental water inflow. Additional advantage would be information about the ground water level. It is suggest to take action by the treatment plant operator to obtain this information and based on this information perform detailed analysis.

4. Considering the results of this study, it was concluded that in the investigated multi-year period the wastewater treatment plant in Jasło operated in hydraulic underload conditions. According to BUGAJSKI and SATORA [2009] and BUGAJSKI [2009], hydraulic underload is primarily due to lower water consumption by residents, compared to the standard consumption assumed during the facility design and increasing environmental awareness of the residents who try to conserve water resources. Moreover the daily flow from one person has changed from 0.2 $\mathrm{m}^{3} \cdot \mathrm{d}^{-1} \cdot \mathrm{P}^{-1}$ in the 1970 to the $0.12 \mathrm{~m}^{3} \cdot \mathrm{d}^{-1} \cdot \mathrm{P}^{-1}$ now, what was resulted from changes in taxes for water.

\section{REFERENCES}

Bergel T., Bugajski P., Pawelek J. 2013. Analysis of the sewage system expandability in Mściwojów commune. Geomatics, Landmanagement and Landscape. No. 2 p. 7-14.

Bergel T., PAweleK J. 2005. Struktura zużycia wody w gospodarstwach wiejskich [Structure of water consumption in rural households]. Ochrona środowiska, walory przyrodnicze i rozwój turystyki w dolinie Sanu. Materiały z II Konferencji Naukowo-Technicznej „Błękitny San" [Environmental protection, natural values and tourism development in the San valley. Proceedings of the 2nd Scientific and Technical conference "Blue San"] p. 165-173.

BUGAJSKi P. 2007. Dynamika dopływu ścieków do oczyszczalni w Głogowie Małopolskim [Dynamics flow to sewage treatment plant in Głogów Małopolski]. Infrastruktura i Ekologia Terenów Wiejskich. Nr 2 p. 103109.

BugajSKi P., Bergel T. 2009. Niedociążenia hydrauliczne przydomowych oczyszczalni ścieków [Underloading of hydraulic in domestic sewage treatment plant]. Infrastruktura i Ekologia Terenów Wiejskich. Nr 5 p. 147154.

Bugajski P., Kaczor G. 2005. Przydomowe oczyszczalnie jako uzupełniający element unieszkodliwiania ścieków na terenach wiejskich [Domestic sewage treatment systems as an additional method of sewage disposal in rural areas]. Ochrona środowiska, walory przyrodnicze i rozwój turystyki w dolinie Sanu. Materiały z II Konferencji Naukowo-Technicznej „Błękitny San” [Environmental protection, natural values and tourism development in the San valley. Proceedings of the 2nd Scientific and Technical conference "Blue San"] p. 149-163.

Bugajski P., PAweŁeK J. 2005. Struktura zużycia wody w gospodarstwach wiejskich [Structure of water consumption in rural households]. Ochrona środowiska, walory przyrodnicze i rozwój turystyki w dolinie Sanu. Materiały z II Konferencji Naukowo-Technicznej „Błę- kitny San" [Environmental protection, natural values and tourism development in the San valley. Proceedings of the 2nd Scientific and Technical conference "Blue San"] p. 165-173.

BugajSKi P., SATORA S. 2009. Bilans ścieków dopływających i dowożonych do oczyszczalni na przykładzie wybranego obiektu [The balance of sewage inflowing and brought to the treatment plant based on example of the chosen object]. Infrastruktura i Ekologia Terenów Wiejskich. Nr 5 p. 73-82.

CHMIElOWSKI K., BUGAJSKI P., WĄSIK E. 2015. Ocena działania oczyszczalni ścieków w Haczowie przed i po modernizacji [Assessment of the operation of a sewage treatment plant in Haczów before and after modernization]. Infrastruktura i Ekologia Terenów Wiejskich. $\mathrm{Nr} 4$ p. 949-964.

Giokas D.L., Vlessidis A.G., Angelidis M.O., TsimaRAKIS G. J., KARAYANNIS M. I. 2002. Systematic analysis of the operational response of activated sludge process to variable wastewater flows. A case study. Clean Technologies and Environmental Policy. No 4. Iss. 3 p. $183-190$.

HeIDRICH Z. 1998. Przydomowe oczyszczalnie ścieków. Poradnik [Domestic sewage treatment systems. Guide]. Warszawa. CIOB. ISBN 83-85393-55-2 pp. 220.

KACZOR G. 2006. Jednostkowe odpływy ścieków z kanalizacji wiejskiej w gminie Koszyce [Unit sewage outflows from rural sewer system in Koszyce municipality]. Infrastruktura i Ekologia Terenów Wiejskich. Nr 2 p. $171-182$.

KACZOR G. 2009. Otwory we włazach studzienek kanalizacyjnych jako jedna z przyczyn przedostawania się wód przypadkowych do sieci rozdzielczej [Holes in the sewage canals' hatches as one of the cause for the accidental water infiltration to the separate sewer system]. Infrastruktura i Ekologia Terenów Wiejskich. $\mathrm{Nr} 9$ p. $155-163$.

KACZOR G. 2011. Wpływ wiosennych roztopów śniegu na dopływ wód przypadkowych do oczyszczalni ścieków bytowych [Impact of spring snowmelt on inflows to the household sewage treatment plant]. Acta Scientiarum Polonorum. Formatio Circumiectus. Nr 2 p. 27-34.

KaCzor G., Bugajski P., Bergel T. 2013. Zastosowanie metody trójkąta do obliczania objętości wód infiltracyjnych i przypadkowych w kanalizacji sanitarnej [Application of the triangle method for the calculation of the infiltration and inflow volume in a sanitary sewer system]. Infrastruktura i Ekologia Terenów Wiejskich. Nr 3 p. 263-274.

Kaczor G., PaweŁeK J. 1999. Dobowe ilości ścieków w osiedlach wiejskich w aspekcie ich oczyszczania [Daily amount of sewage discharged from rural settlements and treatment solutions]. Zeszyty Naukowe Akademii Rolniczej w Krakowie. Nr 350 p. 103-113.

KaCzor G., PrZebinda A. 2009. Analiza uszkodzeń kanałów sanitarnych po krótkim okresie eksploatacji [An analysis of sanitary sewer damage after a short period of operation]. Inżynier Budownictwa. Nr 11 p. 56-59.

KŁACZYŃSKi K., RATAJCZAK P. 2012. Oczyszczalnia ścieków - bilans jakościowy i ilościowy [Wastewater treatment plant - quantity and quality balance]. Wodociagi - Kanalizacja. Nr 1 p. 33-34.

LIPIŃSKA E.J. (ed.) 2011. Powódź 2010 - przyczyny i skutki [The flood of 2010 - causes and consequences]. Biblioteka Monitoringu Środowiska. Rzeszów. WIOŚ pp. 254.

MASŁOŃ A. 2014. Evaluation of the effectiveness of wastewater treatment plant in Jasło under different hydraulic 
loading. Archiwum Gospodarki Odpadami i Ochrony Środowiska. Nr 14 p. 57-66.

MieRniK W., MŁYŃSKi D. 2014. Analiza pracy oczyszczalni ścieków w Krzeszowicach po modernizacji [Operation of a wastewater treatment plant in Krzeszowice after modernization]. Episteme. Nr 29 p. 303-310.

MierNiK W., WALĘGA A. 2013. Usuwanie ze ścieków związków organicznych i biogennych w oczyszczalni $\mathrm{z}$ reaktorem biologicznym funkcjonującym w układzie A2/O [Removal of organic compounds and nutrients from sewage in a wastewater treatment plant with a bioreactor operating in $\mathrm{A} 2 / \mathrm{O}$ system]. In: Wybrane aspekty ochrony i kształtowania środowiska w Polsce, we wschodniej Słowacji i zachodniej Ukrainie [Selected aspects of environmental protection and monitoring in Poland, eastern Slovakia and western Ukraine]. Ed. J. Rak. Brzozów. Wydaw. Muzeum Regionalnego im. Adama Fastnachta p. 107-126.

MiKOŁAJCZYK M., KRAJEWSKi P. 2014. Rozwój sieci kanalizacyjnej na terenie gmin wiejskich powiatu jeleniogórskiego [Sewage system development in rural communities of the Jelenia Góra powiat]. Infrastruktura i Ekologia Terenów Wiejskich. Nr 2 p. 307-318.

Mines R.O., LACKey L.W., BeHREND G.R. 2007. The impact of rainfall on flows and loadings at Georgia's wastewater treatment plants. Proceedings of the 2007 Georgia Water Resources Conference p. 1-4.

MŁYŃSKA A. 2014. Experimental analysis of Bielany wastewater treatment plant hydraulic load variability. Technical Transactions. Nr 5-B p. 183-189.

Mucha J. 1994. Metody geostatystyczne w dokumentowaniu złóż [Geostatistical methods for deposit documentation]. Kraków. Wydaw. AGH. ISBN 83-9023651-6 pp. 155 .
Myszograj S., PANeK E. 2007. Bilansowanie ilości ścieków dopływających do oczyszczalni [Balancing the amount of sewage entering a wastewater treatment plant]. Gaz, Woda i Technika Sanitarna. Nr 5 p. 9-12.

PAWEŁEK J., KACZOR G. 2006. Jednostkowe zużycie wody w gospodarstwie domowym w 8-letnim okresie obserwacji [Unit water consumption per household during 8year period of observations]. Infrastruktura i Ekologia Terenów Wiejskich. Nr 2 p. 159-170.

Rauch W., Harremoes P. 1996. The importance of the treatment plant performance during rain to acute water pollution. Water Science and Technology. Vol 34. Iss. 4 p. $1-8$.

Spellman F.R. 2005. Mathematics manual for water and wastewater treatment plant operators. CRC Press. ISBN 9781482224214 pp. 280.

SPELLMAN F.R. 2013. Handbook of water and wastewater treatment plant operations. $3^{\text {th }}$ ed. CRC Press. ISBN 9781466553378 pp. 923.

Stricker A., Lessard P., Heduit A., Chatellier P. 2003. Observed and simulated effect of rain events on the behavior of an activated sludge plant removing nitrogen. Journal of Environmental Engineering and Science. No 2. Iss. 6 p. $429-440$.

Toet S., VAN Logtestijn S.P., KAMPF R., SChreiJer M., VERHOEVEN J.T.A. 2005. The effect of hydraulic retention time on the removal of pollutants from sewage treatment plant effluent in a surface-flow wetland system. The Society of Wetland Scientists. No 25 p. 375 391.

Xu J., Zhang G., LiU J., ZhU Y. 2015. Effect of hydraulic loading rate on the efficiency of effluent treatment in a recirculating puffer aquaculture system coupled with constructed wetlands. Journal of Ocean University of China. Vol. 13. Iss. 1 p. 146-152.

\section{Dariusz MŁYŃSKI, Krzysztof CHMIELOWSKI, Anna MŁYŃSKA}

\section{Analiza obciążenia hydraulicznego oczyszczalni ścieków w Jaśle}

\section{STRESZCZENIE}

Słowa kluczowe: ilość ścieków, obciażenie hydrauliczne, oczyszczalnie ścieków, ścieki

W artykule przedstawiono analizę obciążenia hydraulicznego oczyszczalni ścieków w Jaśle. Badania przeprowadzono na podstawie rejestrów dobowych objętości ścieków dopływających do oczyszczalni w wieloleciu 2010-2014. Wyznaczono średnią dobową ilość dopływających ścieków w badanym pięcioleciu, określono maksymalne współczynniki nierównomierności dobowej dopływu ścieków, kształtowanie się wielkości dopływu w poszczególnych miesiącach oraz dni tygodnia analizowanego wielolecia i wyznaczono przedziały klasowe, w których najczęściej pojawiały się dopływy ścieków.

Na podstawie przeprowadzonej analizy stwierdzono, że średnia dobowa ilość ścieków dopływających do oczyszczalni w Jaśle w rozpatrywanym wieloleciu wynosi $13045 \mathrm{~m}^{3} \cdot \mathrm{d}^{-1}$. Ilość dopływających ścieków charakteryzuje się nierównomiernością, o czym świadczą wielkości maksymalnych współczynników nierównomierności dobowej dopływu ścieków, które w poszczególnych miesiącach przyjmowały wartości z przedziału od 1,07 do 2,78. Ponadto stwierdzono, że największe dopływy ścieków występują w miesiącach: marzec, maj, czerwiec, a w ciagu tygodnia - w soboty. Analiza częstości wystąpienia poszczególnych ilości ścieków dopływających do jasielskiej oczyszczalni wykazała, że najczęściej pojawiającym się dopływem był dopływ przyjmujący wartości z przedziału od 8000 do $10000 \mathrm{~m}^{3} \cdot \mathrm{d}^{-1}$. Bazując na uzyskanych wynikach, stwierdzono, że oczyszczalnia ścieków w Jaśle pracuje w warunkach niedociążenia hydraulicznego. 